\title{
Studies of the viral flora in keratoconjunctivitis sicca
}

JOHN WILLIAMSON*, W. MALGOLM DOIG $\dagger$, J. V. FORRESTER*, W. GARSON DICK $\ddagger$, AND K. WHALEY

From The Southern General Hospital,* Glasgow, The Victoria Eye Infirmary, $\dagger$ Paisley, and The Centre for Rheumatic Diseases, $\ddagger$ University Department of Medicine, Glasgow

In studies of the presenting signs and symptoms of newly diagnosed untreated keratoconjunctivitis sicca (KCS), a variety of corneal staining patterns with fluorescein can be detected in 30 per cent. of cases (Williamson, Whaley, Dick and Anderson, 197I; Anderson, Whaley, Williamson, and Buchanan, 1972). Appearances include isolated punctate erosions, linear and confluent erosions, widespread punctate erosions, and keratitis reminiscent of a variety of virus and TRIC agent infections.

Herpes simplex corneal ulceration in KCS was observed by Jones and Coop (1965), who considered a proportion of their patients to be carriers of the virus. However, it would appear that no analysis of virus infection in patients with KCS has been recorded, although bacterial and fungal studies showing increased susceptibility to colonization have been completed (Williamson, Wilson, Wallace, and Whaley, 1971 ; Williamson, Gordon, Wood, Dyer and Yahya 1968).

In this study, we attempted to classify the lesions of $5^{8}$ patients suffering from KCS and to examine the corneal cells for the presence of herpes simplex, adenovirus, and TRIC agent infection (Table).

Table Suspected virus involvement in KCS patients

\begin{tabular}{lrrrr}
\hline Technique & $\begin{array}{c}\text { Immuno- } \\
\text { fluorescein }\end{array}$ & $\begin{array}{c}\text { Tissue } \\
\text { culture }\end{array}$ \\
\cline { 1 - 1 } Adenovirus punctate keratitis & & 14 & & 12 \\
Herpetic punctate keratitis & & 7 & & 6 \\
TRIc agent & & & 2 \\
Dendritic herpetic ulceration & & 2 & & 2 \\
Amoeboid herpetic ulceration & & 1 & & 2 \\
Uncertain & & 4 & & 4 \\
\cline { 1 - 1 } Total patients & & 30 & & 28 \\
\hline
\end{tabular}

Address for reprints: John Williamson, M.D., F.R.C.S., Southern General Hospital, Govan Road, Glasgow.

\section{Material and methods}

PATIENTS STUDIED

Thirty patients suffering from KCS who exhibited any of the fluorescein staining patterns of the cornea described above were examined for evidence of virus infection by immunofluorescein techniques. The investigations were repeated in eight of these patients and in a further twenty patients using standard tissue culture methods (Table; Figure).

\section{CELLS}

Suspect corneal epithelial cells were removed with a flattened aluminium spatula after instillation of a 1 per cent. solution of amethocaine. The cells were spread over a clear glass slide, dried at room temperature, fixed in go per cent. acetone for 90 sec., and transported immediately to the laboratory. According to the methods in current use at the department of Virology, Belvedere Hospital, a polyvalent serum containing antibodies to herpes simplex, adenoviruses 3, 7, 8, and 14, and the TRIC group was developed in rabbits. This antiserum was conjugated with fluorescein, thereby rendering any reaction with appropriate virus antigen contained in the corneal cells visible under ultraviolet light.

\section{CULTURE}

Specimens of corneal cells for tissue culture were obtained by scraping the corneal surface with sterile cotton-tipped sticks, the ends of which were broken off and immersed in screw-topped bottles containing tissue culture medium of HeLa cells. The specimens were transported immediately to the University Department of Virology, Gardiner Institute, Glasgow, where they were incubated for up to 4 weeks, and examined by the current methods in use at the department for the isolation of herpes or adenovirus.

\section{Results}

No viruses were detected by either method

\section{Discussion}

This study has failed to show any evidence of herpes simplex, adenovirus, or TRIC agent in the corneal 


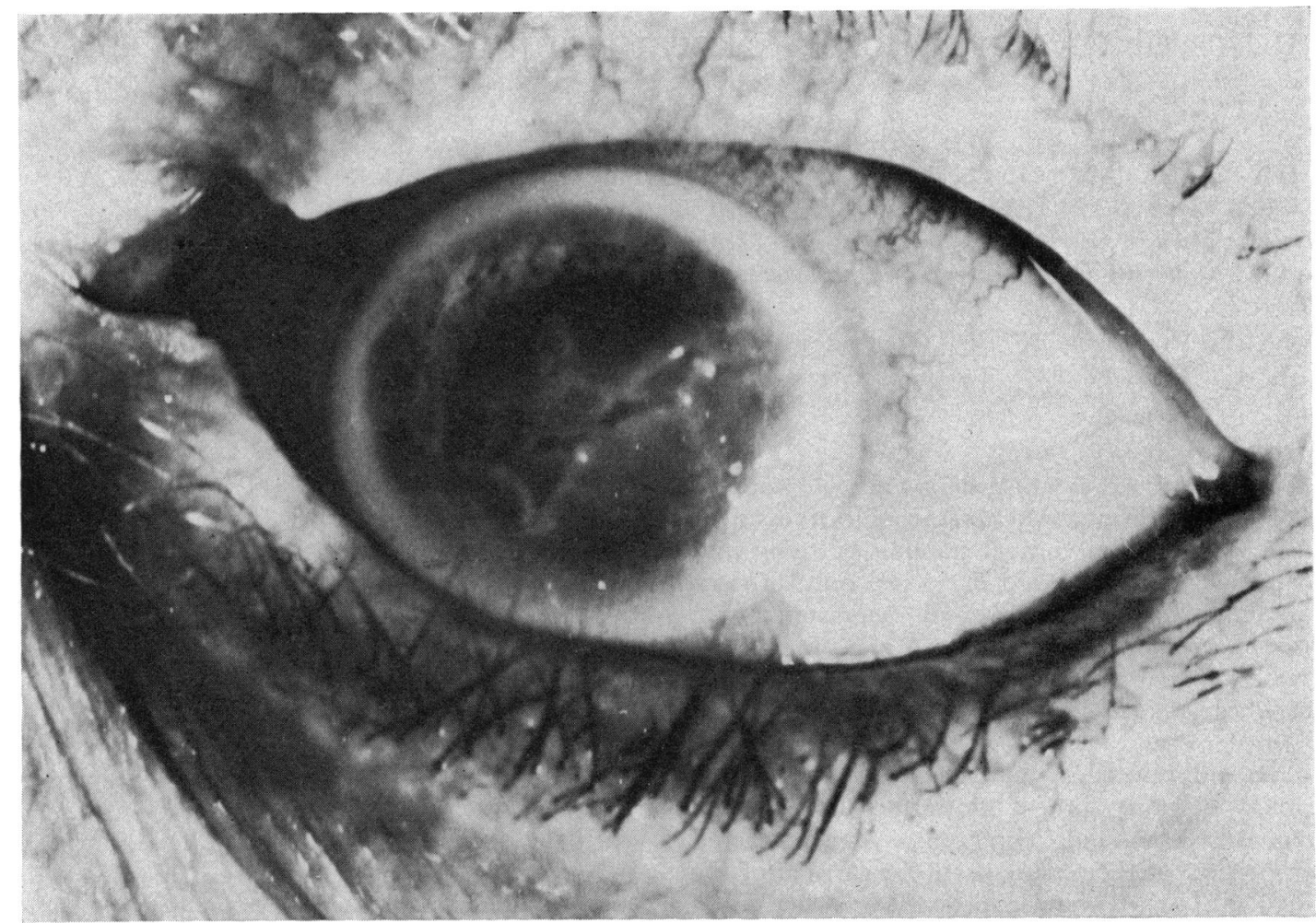

FIGU RE Amoeboid herpetic ulceration in keratoconjunctivitis sicca

cells of patients suffering from KCS. The procedure for obtaining corneal specimens for tissue culture is well established and has resulted in a 90 per cent. isolation rate for herpes simplex from dendritic ulcers diagnosed at the University Department of Ophthalmology, Glasgow. The Figure certainly shows a dendritic-like ulcer and it is difficult to explain the negative results in such a case. Possibly the patient was suffering from a form of corneal ulceration akin to spontaneous corneal perforation. On the other hand, reduced corneal sensitivity was not recorded in any case.

An evaluation of immunofluorescence techniques is beyond the scope of this communication. It is suffcient to record at present that no viruses were detected by this method in thirty patients, and eight of these were further examined by tissue culture on HeLa cells with negative results.
It has long been presumed that viruses are causal factors in the recurrent corneal ulceration of KCS. However, the absence of viruses in fifty patients suffering from KCS, all of whom had corneal fluorescein staining patterns consistent with possible viral keratitis, does not support this belief.

\section{Summary}

Fifty patients suffering from KGS and exhibiting various patterns of corneal staining with fluorescein were examined for adenovirus types 3, 7, 8, and 14 , herpes simplex, and the TRIC group by tissue culture and immunofluorescein techniques. No viruses were detected by either method, and it is considered that presumption of virus involvement in these cases is untenable.

\section{References}

anderson, J. A., Whaley, K., williamson, J., and buchanan, w. w. (1972) Quart. F. Med., 41, i62, i 75 JONES, B. R., and COOP, H. v. (1965) Trans. ophthal. Soc. U.K., 85, 379.

Williamson, J., GORDON, A. M., WOOD, R., DYER, A. MCK., and YAHYA, O. A. (1968) Brit. F. Ophthal., 52, 127

-, WHALEY, K., DICK, W. c., and ANDERSON, J. A. (197I) Trans. ophthal. Soc. U.K., 91, 147 , wilson, t., Wallace, J., and whaley, K. (197I) Eye, Ear, Nose Thr. Monthly, 50, 257 